\title{
Gesture Control Menggunakan IMU MPU 6050 Metode Kalman Filter Sebagai Kendali Quadcopter
}

\author{
(Gesture Control Using IMU MPU 6050 \\ Kalman Filter Method for Quadcopter Control)
}

\author{
Rudi Setiawan ${ }^{1}$, Hendri Himawan Triharminto², Muhammad Fahrurozi ${ }^{3}$ \\ 1,2,3 Prodi Elektronika Pertahanan, Akademi Angkatan Udara \\ E-mail: rudisetiawan@aau.ac.id,hhtriharminto@gmail.com., muhammadfahrurozi@aau.ac.id
}

\begin{abstract}
The main task of the Indonesian Air Force is to uphold sovereignty in the territory of Indonesia, so it requires human resources capable of defense equipment in accordance with the development of science and technology. One of the most important technologies is unmanned aircraft, so the research is expected to develop a drone control system with gestures, a communication system from radio to wireless and increase the accuracy of the gyroscope sensor with the Kalman filter algorithm. The system was built using a DJI Tello quadcopter drone with a gyroscope sensor using an IMU MPU 6050 and a processing system using Arduino Uno with Arduino Sketch software for kalman filter and wireless communication with Python. The system can control the drone with gestures for take off operations at an angle of 60 to 90 pitch angles, for landing at an angle of -60 to -90 , for 362 data retrieval on the kalman filter method with a minimum variation of 0.00166 and a variation of 0.00564 in a range of 89.25 to 89.30. On roll with gesture to the right, if it is more than 30 to 90 and gesture to the left if it is more than -30 to $\mathbf{- 9 0}$ with a minimum variance of 0.0456 and a variance of 0.0141 at an angle of 90.42 to 90.44 of 362 experimental data samples, the system can communicate with the Wireless system
\end{abstract}

Keywords - Gesture, MPU 6050, wireless, kalman filter

Abstrak-Tugas pokok TNI AU yaitu menegakkan kedaulatan diwilayah Indonesia maka diperlukan sumber daya manusia yang berkemampuan alutsista sesuai perkembangan ilmu dan teknologi. Ssalah satu teknologi pesawat tanpa awak sangat penting maka penelitian diharapkan berkembangan sistem kendali drone dengan gesture, sistem komunikasi dari radio ke wireless dan peningkatan akurasi sensor gyroscope dengan alogaritma Kalman filter. Sistem dibangun dengan menggunakan drone quadcopter Dji tello dengan sensor gyroscope menggunakan IMU MPU 6050 dan sistem pengolah mengunakan Arduino Uno menggunakan software Sketch Arduino untuk kalman filter serta komunikasi wireless dengan Python. Sistem dapat mengendalikan drone dengan gesture pada operasi take off pada susdut 60 sampai 90 sudut pitch, untuk landing pada sudut -60 sampai -90, untuk 362 pengambilan data pada metode kalman filter variasi minamal 0,00166 dan variasi 0.00564 pada range 89.25 sampai 89.30 . untuk roll dengan cara gesture kekanan jika lebih 30 sampai 90 dan gesture kekiri jika lebih -30 sampai -90 dengan varian minimal 0.0456 dan varial 0.0141 pada sudut 90.42 sampai 90.44 dari percobaan 362 sampel data, sistem dapat komunikasi dengan sistem Wireless

Kata Kunci- Gesture, MPU 6050, wireless, kalman filter

*Penulis Korespondensi (Rudi Setiawan)

E-mail: rudisetiawan@aau.ac.id 


\section{Pendahuluan}

SAlah satu tugas pokok TNI Au adalah menegakan kedaulatan seluruh wilayah Indonesia

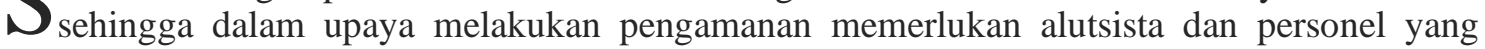
handal untuk mengawakinya. UAV pada TNI AU berperan sebagai Intelegent Surveillance reconnaissance(ISR) udara, sehingga memudahkan memudahkan TNI AU dalam melaksanakan tugas pokok pengamatan udara didaerah perbatasan dengan memperimbangan perkembangan teknologi sekarang. Salah satu jenis UAV adalah Quadcopter Drone yang menggunakan empat buah motor sebagai penggeraknya [1], pengendalikan navigasi sebagai cara remote control atau dengan menggunakan natural user interface (INU). INU merupakan metode antarmuka pengguna yang menggunakan kemampuan alami manusia untuk berinteraksi dengan sistem [2,3]. Penelitian Muh Irham Romandon (2019) pada Gesture recogniton menggunakan sensor Inertial Measurement Unit (IMU) terfilter Complimentary filter dengan hasil kurang akurasi sudut dalam kendali navigasi. Hand Gesture dengan sensor utama Gyroscope mengendalikan drone pengamatan menggunakan komunikasi radio frekwensi 2,4 Ghz terkendali kendali PID [5,6], Gerak tubuh dapat mengendalikan drone dengan sensor 3 infrared menggunakan mikroprosesr arm cortex A8 sebagai rekontruksi perintah untuk dikomunikasi pada frekwensi wifi dengan software pendukung Python [7], Gerak tubuh mengendalikan drone dengan sensor kamera pada komunikasi wifi memakai drone Parrot dengan software pendukung Python[8]. Gestur tangan dengan IMU menggunakan metode kalman filter meningkatkan akurasi dan menurunkan errror bias 0.003 pada sudut 0.03 derajat [9]. Pada penelitian ini akan dilakukan penerapan alogaritma Kalman filter untuk meningkatkan akurasi sudut dari sensor gyroscope dengan sudut hubungan roll dan pitch dengan komunikasi sistem wireless. Pokok permasalahannya adalah gesture tangan dapat mengendalikan drone, komunikasi sistem wirelesss dapat diterima drone, pengaruh aliogaritma kalaman filter dapat meningkatkan akurasi dari sensor MPU 6050. Penelitian ini diharapkkan menjadi referensi pembelajaran Mekatronika tentang UAV dengan sensor Gyroscope sebagai pengendalinnya, untuk peneliti dapat menjadi sarana untuk kestabilan errror dan meningkatkan akurasi dengan sistem yang stabil.

\section{LANDASAN TEORI}

Pada bab ini dijelaskan berkaitan dengan spisifikasi drone yang digunakan, implikasi alogaritma kalman filter, arduino Uno, sensor MPU 6050 dengan software pendukung Sketch Arduino dan pemprograman Python sebagai komunikasi sistem wireless ke Drone.

\section{A. Drone}

Quadcopter adalah sebuah helikopter dengan empat motor, rotor diarahkan keatas dengan formasi persegi dengan jarak sama dengan pusat massa Quadcoper. Sistem ini dikendalikan dengan cara mengatur kecepatan putar motor, sistem dapat digunakan sebagai pengawas, pencarian, photo udara dan aplikasi lainnnya. Struktur Quadcopter dalam Gambar 2.1 termasuk kecepatan sudut, torsi dan gaya yang diciptakan oleh empat motor (bernomor dari 1 sampai 4 )[1]. Dji Tello merupakan jenis Drone Quadcopter dirancang oleh Ryze Tecnology yang mempunyai karakteristik berat $80 \mathrm{~g}$, dimensi 98x92x41, propeller, komunikasi wifi frekwensi 2,4 G Hz, jarak terbang $100 \mathrm{~m}$, kecepatan maksimal 8m/detik dan waktu terbang 13 menit.

Posisi quadcopter diterjemahkan tiga dimensi sumbu $\mathrm{x}, \mathrm{y}$, dan z dengan nama matriks $\xi$. Posisi sudut didefinisikan sebagai arah drone dalam frame inersia dengan tiga sudut Euler $\eta$ yaitu sudut pitch $\theta$ menentukan rotasi quadcopter di sekitar sumbu y, sudut roll $\varphi$ menentukan rotasi sekitar sumbu x dan sudut yaw $\psi$ sekitar sumbu z. Vektor q berisi vektor posisi linear dan posisi sudut. 

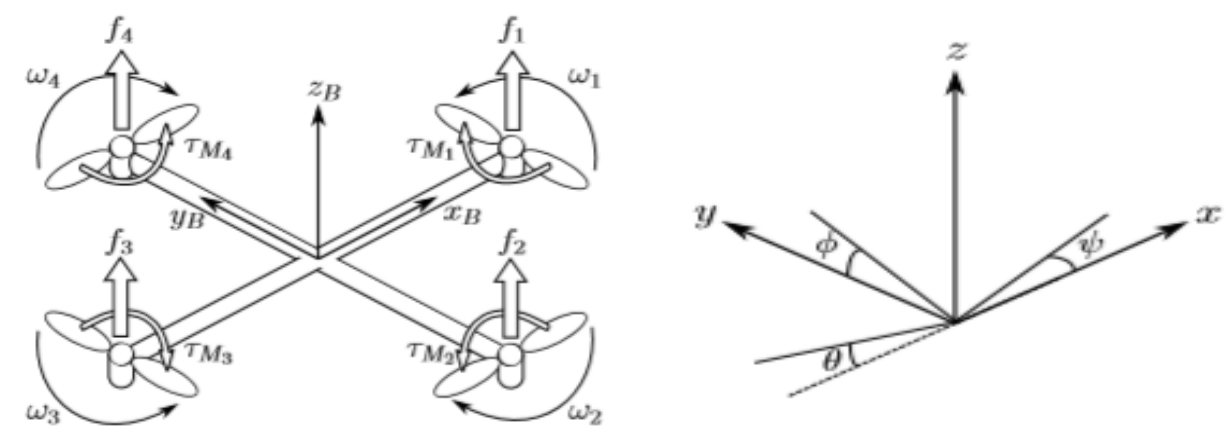

Gambar 1. Inersia dari Quadcopler

$$
\xi=\left[\begin{array}{l}
x \\
y \\
z
\end{array}\right], \quad \eta=\left[\begin{array}{l}
\phi \\
\theta \\
\psi
\end{array}\right], \quad q=\left[\begin{array}{l}
\xi \\
\eta
\end{array}\right]
$$

Titik tengah adalah di pusat massa quadcopter. Dalam frame inersia, kecepatan linier ditentukan oleh VB dan kecepatan sudut oleh V.

$$
V_{B}=\left[\begin{array}{c}
v_{x}, B \\
v_{y}, B \\
v_{z}, B
\end{array}\right], \quad v=\left[\begin{array}{l}
p \\
q \\
r
\end{array}\right]
$$

Matriks rotasi dari body frame ke frame inersia adalah di mana $\mathrm{Sx}=\operatorname{Sin}(\mathrm{x})$ dan $\mathrm{Cx}=\cos (\mathrm{x})$. Matriks rotasi $\mathrm{R}$ adalah ortogonal sehingga $\mathrm{R}-1=\mathrm{RT}$ yang merupakan matriks rotasi dari frame inersia ke body frame.

$$
\boldsymbol{R}=\left[\begin{array}{ccc}
C_{\psi} C_{\theta} & C_{\psi} S_{\theta} S_{\phi}-S_{\psi} C_{\theta} & C_{\psi} S_{\theta} C_{\phi}+S_{\psi} S_{\phi} \\
S_{\psi} C_{\theta} & S_{\psi} S_{\theta} S_{\phi}+C_{\psi} C_{\theta} & S_{\psi} S_{\theta} C_{\phi}-C_{\psi} S_{\phi} \\
-S_{\theta} & C_{\theta} S_{\phi} & C_{\theta} C_{\phi}
\end{array}\right]
$$

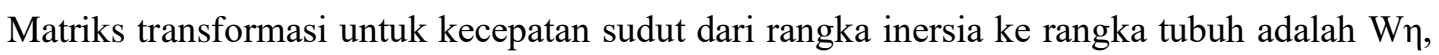
dan dari rangka tubuh ke rangka inersia adalah $\mathrm{W \eta}-1$

$$
\begin{gathered}
\eta=W_{\eta}^{-1} v,\left[\begin{array}{l}
\phi \\
\theta \\
\psi
\end{array}\right]=\left[\begin{array}{ccc}
1 & S_{\phi} T_{\theta} & C_{\phi} T_{\theta} \\
0 & C_{\phi} & -S_{\phi} \\
0 & S_{\phi} / C_{\theta} & C_{\phi} / C_{\theta}
\end{array}\right]\left[\begin{array}{l}
p \\
q \\
r
\end{array}\right], \\
v=W_{\eta} \eta, \quad\left[\begin{array}{l}
p \\
q \\
r
\end{array}\right]=\left[\begin{array}{ccc}
1 & 0 & -S_{\theta} \\
0 & C_{\phi} & C_{\theta} S_{\phi} \\
0 & -S_{\phi} & C_{\theta} C_{\phi}
\end{array}\right]\left[\begin{array}{l}
\phi \\
\theta \\
\psi
\end{array}\right],
\end{gathered}
$$

Matriks $W \eta$ adalah invertible jika $\theta \neq(2 \mathrm{k}-1) \varnothing / 2$, $(\mathrm{k} \in \mathrm{Z})$. Quadcopter diasumsikan memiliki struktur simetris dengan empat lengan selaras dengan sumbu tubuh x dan y. Dengan demikian, matriks inersia adalah matriks diagonal saya di mana Ixx = Iyy 


$$
I=\left[\begin{array}{ccc}
I_{x x} & 0 & 0 \\
0 & I_{x x} & 0 \\
0 & 0 & I_{x x}
\end{array}\right]
$$

Kecepatan sudut rotor i, dilambangkan dengan $\omega$ i, menghasilkan gaya fi ke arah sumbu rotor. Kecepatan sudut dan percepatan rotor juga membuat TMi torsi di sekitar sumbu rotor

$$
f_{i}=k w_{i}^{2}, \quad \tau M_{1}=b w_{i}^{2}+I_{M w_{i}},
$$

di mana konstanta lift adalah $\mathrm{k}$, konstanta drag adalah $\mathrm{b}$ dan inersia rotor adalah Im. Biasanya efek $^{*} \omega$ i dianggap kecil dan dengan demikian itu dihilangkan. Kekuatan gabungan rotor membuat gaya dorong $\mathrm{T}$ ke arah sumbu z. Torsi TB terdiri dari torsi $\mathrm{T} \varphi, \mathrm{T} \theta$ dan $\mathrm{T} \psi$ ke arah sudut rangka tubuh yang sesuai

$$
\begin{gathered}
T=\sum_{i=1}^{4} f_{i}=k \sum_{i=1}^{4} w_{i}^{2}, \quad T^{B}=\left[\begin{array}{l}
0 \\
0 \\
T
\end{array}\right], \\
\tau_{B}=\left[\begin{array}{c}
\tau_{\phi} \\
\tau_{\theta} \\
\tau_{\psi}
\end{array}\right]=\left[\begin{array}{c}
l k\left(-w_{2}^{2}+w_{4}^{2}\right. \\
l k\left(-w_{1}^{2}+w_{3}^{2}\right. \\
\sum_{i=1}^{4} \tau M_{i}
\end{array}\right],
\end{gathered}
$$

di mana 1 adalah jarak antara rotor dan pusat massa quadcopter. Dengan demikian, gerakan roll diperoleh dengan mengurangi kecepatan rotor 2 dan meningkatkan kecepatan rotor 4. Demikian pula, gerakan pitch diperoleh dengan mengurangi kecepatan rotor 1 dan meningkatkan kecepatan rotor 3. Gerakan yaw diperoleh dengan meningkatkan kecepatan sudut dua rotor yang berlawanan dan mengurangi kecepatan dua lainnya.

\section{B. Sensor MPU6050}

Sensor gerak MPU6050 adalah sensor dengan 16 bit ADC yang memiliki 3 axis gyroscope, 3 axis accelerometer dan sebuah Digital Motion Processor (DMP) untuk mengukur posisi dari sebuah benda. Sensor ini akan mengambil data dari gyroscope dan accelerometer pada saat sinkronisasi pengambilan sampel data yang ditetapkan,yaitu data gyroscope 3-Axis, data accelerometer 3-Axis, dan data suhu. MPU6050 adalah smatch sensor yang didalamnya terdapat tranduser, memori, ADC, Mikrokontroler dan interface dengan data keluaran 16 bit sehingga akurasinya sangat tinggi. Gambar sensor MPU6050 dapat dilihat pada Gambar 2

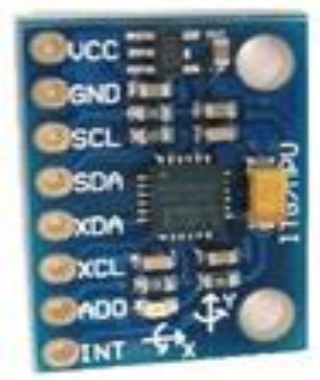

Gambar 2.

Sensor MPU6050 


\section{Kalman Filter}

Kalman Filter adalah adalah suatu persamaan matematis yang menghasilkan suatu perhitungan rata-rata rekursif yang efisien untuk mengestimasi suatu keadaan dari sebuah proses yang bertujuan untuk mengurangi rata-rata error. Kalman Filter juga merupakan suatu estimator rekursif, dengan kata lain hanya dibutuhkan keadaan hasil estimasi dari pewaktuan sebelumnya dan hasil pengukuran saat ini untuk dapat menghitung estimasi keadaan saat ini[4].

Kalman Filter pertama kali dikenalkan oleh Rudolf Emil Kalman pada tahun 1960 melalui makalahnya yang berujudul "A New Approach to Linear Filtering and Prediction Problems". Ia mempublikasikan sebuah metode untuk memprediksi keadaan suatu objek bergerak menggunakan nilai keadaan sebelumnya. Selain itu, Kalman Filter juga digunakan untuk mengatasi ketidakstabilan data input akibat gangguan noise atau derau. berikut[5].

Secara umum perumusan Kalman Filter digambarkan pada Gambar 2.3 sebagai

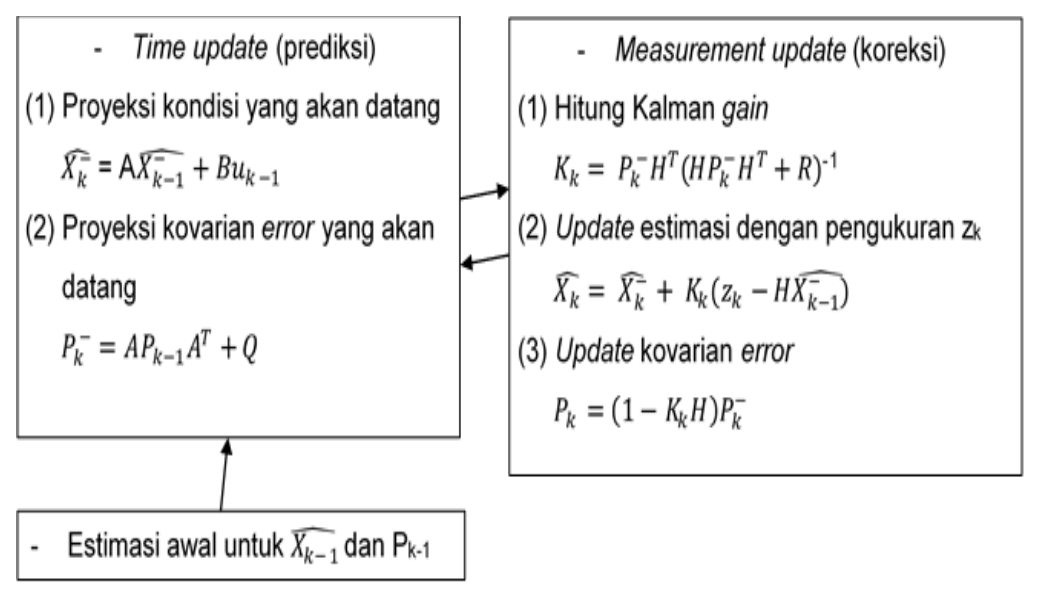

Gambar 3. Proses Kalman Filter

Misalkan merupakan perkiraan keadaan suatu objek yang dinyatakan dalam bentuk posisi dan kecepatan dengan nilai rata-rata (mean) $\mu$ dan memiliki matriks kovarian Pk. Maka dapat dituliskan dalam persamaan matriks berikut :

$$
\begin{gathered}
\widehat{x_{k}}=\left[\begin{array}{c}
\text { posisi } \\
\text { kecepatan }
\end{array}\right] \\
P_{k}=\left[\begin{array}{ll}
\Sigma p p & \Sigma p v \\
\Sigma v p & \Sigma v v
\end{array}\right]
\end{gathered}
$$

Untuk menghitung prediksi keadaan, maka digunakan nilai keadaan objek sebelumnya, persamaan matematis gerak dasar yang dapat ditulis adalah sebagai berikut :

$$
\begin{aligned}
V_{k}=V_{k-1}+a & \Delta t \\
p_{k}= & p_{k-1}+\Delta t V_{k-1}+\frac{1}{2} a \cdot \Delta t^{2} \\
\widehat{x_{k}} & =\mathrm{A} \widehat{x_{k-1}}+\left[\begin{array}{c}
\frac{\Delta t^{2}}{2} \\
\Delta t
\end{array}\right] a \\
& =A \cdot \widehat{x_{k-1}}+B \cdot \overrightarrow{u_{k}}
\end{aligned}
$$


Matriks A merupakan matriks prediksi sedangkan B adalah matriks control dengan sebagai control input. Objek yang dinyatakan dalam mendapatkan noise yang berasal dari lingkungan luar (dinyatakan dengan matriks kovarian Q). Noise ini berpengaruh pada perhitungan prediksi dan dapat ditulis sebagai berikut :

$$
P_{k}=A \cdot P_{k-1} \cdot A^{T}+Q
$$

Selain perhitungan prediksi kondisi yang akan datang oleh Kalman Filter (predicted measurement), nilai akhir prediksi juga dipengaruhi oleh pembacaan/pengukuran sensor (observed measurement) yang dinyatakan dengan matriks $\mathrm{H}$ yang memiliki nilai rata-rata dengan kovarian R. Hasil pembacaan sensor dan perhitungan Kalman ini digabungkan untuk memperoleh hasil prediksi yang lebih baik dengan mencari nilai yang bertumpang tindih (overlap). K merupakan matriks yang disebut dengan Kalman gain. Penggabungan tersebut dinyatakan dalam persamaan :

$$
\begin{aligned}
& \widehat{x_{k}}=\widehat{x_{k-1}}+K\left(\overrightarrow{z_{k}}-H \cdot \widehat{x_{k-1}}\right) \\
& P_{k}=P_{k-1}-K \cdot H \cdot P_{k-1} \\
& K=P_{k-1} H^{T}\left(H \cdot P_{k} \cdot H^{T}+\mathrm{R}\right)^{-1}
\end{aligned}
$$

\section{Arduino Uno}

Hardware arduino berisi mikrokontroler AVR buatan Atmel 328. Software arduino terdiri dari bahasa pemrograman dan Integrated Development Environtment (IDE) yang gratis untuk di download. Pada Arduino Uno mempunyai tegangan operasi antara $5 \mathrm{sd} 9$ volt, didalam terdapat mikrokontroler atmega 328 dengan 6 masukan analog 10 bit, 14 masukan digital, 3 komunikasi serial yaitu USART, TWI dan SPI, kecepatan clok 16 MHZ, memori 2 Kbyte RAM, 1 Kbyte EEPROM dan 32 Kbyte flash memori.

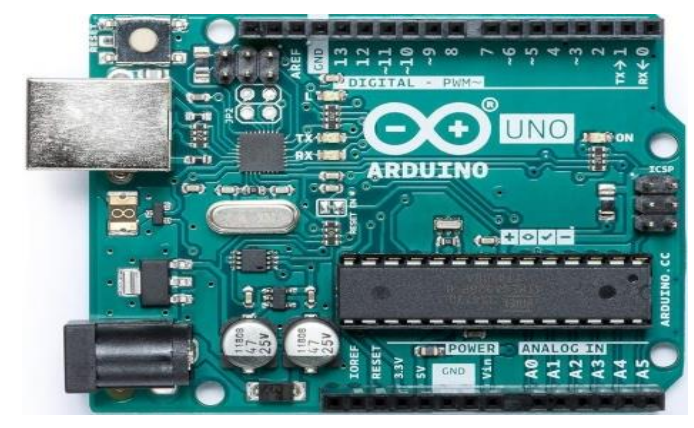

Gambar 4. Arduino Uno

\section{E. Sketch Arduino}

Sketch arduino adalah program open source yang berdasar program bahasa $\mathrm{C}$ dengan perintah yang menyesuaikan hardaware Arduino. Program ini terdiri dari deklarasi/pustaka ditandai include, tipe data dll, Konfigurasi sistem ditandai dengan void setup ()\{\} , dan program utama ditandai dengan void loop ()\{\} atau anak program berupa fungsi atau perintah. 


\section{F. Python}

Phython arduino adalah program open source yang berdasar program bahasa visual yang dapat include dengan program aplikasi visual sesuai protokol internet dan mempunyai library pengembangan teknologi internet sehingga pada penelitian ini menggunakan sistem wirelees sangat cocok untuk komunikasi perintah dalam bentuk software Phyron. Program phyton mempunyai library nya Ethernet.begin (Mac, IP address), server . begin () sebagai konfigurasi sistem .

\section{Model YANG DiUSULKAN}

Tahapan penelitian dilakukan adalah pertama Studi pustaka. Pada tahapan ini, studi literatur terhadap penelitian-penelitian yang telah dilakukan oleh penelitian sebelumnya, dianalisis secara kritis untuk menentukan gap penelitian, kedua merumuskan pokok masalah berdasarkan hasil kajian literatur, maka dapat ditentukan gap permasalahan yang ada untuk diselesaikan dalam penelitian ini sehingga tujuan penelitian dapat ditentukan, ketiga adalah perancangan perangkat keras dengan drone DJI Tello dan perangkat lunak Sketch arduino dann Phyton . Keempat adalah Pengujian alat terhadap hasil parameter akurasi sudut gerak drone yang didapatkan dari input gerak tangan yang diberikan, dilakukan dengan cara menentukan sudut dengan mengukur sudut MPU6050 yang dilakukan dengan menggunakan busur derajat. Setelah dilakukan pengujian didapat hasil berupa jumlah pengujian yang benar pada saat sistem mendeteksi sudut. Hasil dari pengujian ini akan ditampilkan pada grafik dan Pengujian Ketepatan Pergerakkan. Pengujian ini dilakukan untuk mengetahui tingkat akurasi hand gesture yang dilakukan oleh pengguna dan hubungannya dengan pergerakan drone dengan batasan sudut yang diberikan $0^{\circ}-90^{\circ}$ dengan melakukan pengujian sebanyak 5 kali setiap sudut gerak terhadap hand gesture pengguna. Kelima adalah analisis terhadap akurasi sudut dan respon dari sensor gyroscope yang digunakan. Dalam hal ini akurasi dan kecepatan waktu pemrosesan menjadi konstrain yang diperhitungkan. Dengan tahapan perencanaan penelitian sebagai berikut :

\section{A. Rancangan Hardware dan Soft ware}

Pada sistem perangkat keras yaitu sistem sensor Gyroscope, Untuk mengakses sensor MPU6050, dibutuhkan komunikasi inter integrated Circuit (I2C) melalui saluran Serial Clock (SCL) dan Serial Data (SDA). Pada modul Arduino Uno saluran tersebut terdapat pada A4 dan A5 pada Analog. pada MPU6050 yang digunakan yaitu pin VCC dihubungkan dengan pin $3.3 \mathrm{~V}$ pada Arduino, Pin GND dihubungkan dengan pin GND pada Arduino, Pin SCL dihubungkan dengan pin A4, dan pin SDA dihubungkan dengan dengan pin A5 pada Arduino.

\section{B. Rancangan Pengujian dan Evaluasi System}

Metode pengujian dan evaluasi sistem yang akan digunakan adalah Hand Gesture. Hand Gesture sebagai perintah yang dideteksi oleh Gyroscope, Bagian tangan yang dideteksi yaitu bagian tangan sampai pergelangan tangan. Tabel 1 menjelaskan gerakan tangan sebagai kendali drone. Perancangan hand gesture pada dasarnya memanfaatkan transformasi sudut dan perubahan percepatan tangan yang dideteksi oleh sensor MPU6050 ketika tangan digerakan. Dalam mendeteksi transformasi sudut dibutuhkan nilai acuan sebagai pembanding. Nilai acuan tersebut didapatkan dari nilai sudut yang timbul karena adanya perputaran dengan acuan sumbu $\mathrm{x}$ dan $\mathrm{y}$ yaitu sudut roll, yaw dan Pitch. 
TABEL I

PERANCANGAN HAND GESTURE PADA DRONE

\begin{tabular}{|l|l|l|}
\hline \hline \multicolumn{1}{|c|}{ Nama Gesture } & \multicolumn{1}{|c|}{ Keterangan } & \multicolumn{1}{c|}{ Pergerakan Drone } \\
\hline Pitch Up & Tangan digerakan lurus ke atas & Take off dan naik \\
\hline Pitch Down & $\begin{array}{l}\text { Tangan ditegak luruskan ke } \\
\text { bawah }\end{array}$ & Landing dan turun \\
\hline Gesture Roll Kanan & Tangan roll kanan & Roll ke kanan \\
\hline Gesture Roll Kiri & Tangan roll kiri & Roll ke kiri \\
\hline & & \\
\hline
\end{tabular}

\section{HASIL DAN PEMBAHASAN}

Pada bagian ini dijelaskan mengenai hasil pengujian dan analisa dari pengolahan kendali gerak Dji Tello drone dengan sensor MPU6050. Pengujian yang dilakukan meliputi hasil pengujian sudut MPU6050 terhadap sudut gerak yang diberikan serta impelementasi hand gesture dalam pengujian gerak terbang drone terhadap sensor MPU 6050. Pada pengujian ini dijelaskan tentang inisialisasi drone Dji Tello dengan PC pakai Wifi, sensor MPU 6050 diambil data oleh Arduino Uno dengan kalman filter kemudian dikomunikasikan ke PC selanjutknya di kirim ke Dji Tello.

\section{A. Pengujian software}

Pengujian program dimulai dengan menginisialisasi variabel-variabel yang dibutuhkan, kemudian dilanjutkan dengan mendapatkan data dari MPU6080. Kemudian dilanjutkan dengan memproses kedua data tersebut menggunakan persamaan kalman filter. Pada proses analisa di peragkat lunak megunakan dua program yaitu Sketch Arduino dan Phyton 3.5.

1. Sketch Arduino. Pada software ini digunakan untuk mengambil data dari MPU 6050 selanjutnya di olah dengan cara kalman filter kemudian di transmisikan data serial ke PC. Program dibagi tiga bagian yaitu

a). Inialisisasi library, variabel yang digunakan. Library digunakan data adalah komunikasi serial I2C (<Wire.h>), <MPU6050>, dan kalman filter dari Arduino Uno (< Kalman.h $>$ ). Untuk variabel yang digunakan dengan cara menulis tipe data dilanjutkan nama variabel digunakan dan kondisi awal dari nilai variabel tersebut (Kalman KalmanX).

b). Inialisisasi Perangkat keras, inialisasi dilakukan pada perintah Void setup (). Pada penelitian ini komunikasi I2C dengan perintah (Wire.begin()), komunikasi arduino dengan PC dengan perintah (Serial.begin(115200)) selanjutnya pemangilan register register untuk data MPU 6050 dan pengambilan data awal untuk metode kalman filter dengan dua data yaitu Pitch dan Roll .

c). Program utama. Pada progam utama berisi program pengambilan data awal pada register acelerometer $\mathrm{x}, \mathrm{y}, \mathrm{z}$ dan gyroscope gx,gy,gz (accGyrObj.getMotion6(\&ax, \&ay, \&az, \&gx, \&gy, \&gz)), selanjutnya perhitungkan menjadi data Roll dan Pitch dengan Kalman filter kemudian dikirim ke PC dengan perintah Serial.print(kalAngleX).

2. Python. Pada software ini digunakan PC untuk mengambil data dari Arduino secara serial dan dikirim lewat wireless

a). Inialisisasi library, variabel yang digunakan. Library digunakan data adalah import nama library (serial) dan variabel digunakan (pitchRoll $=[0]^{*}$ arrSize)

b). Inialisisasi Perangkat keras dengan cara menginialisasi perangkat serial dengan perintah $($ dataSerial $=$ serial.Serial('COM4', 115200, timeout). 
c). Program utama. Pada progam utama berisi program pengambilan data serial sesuai dengan format yang ditansmisikan Arduino kemudian dipisahkan menjadi data roll dan pitch. Data dari roll dan pitch di lakukan operasi aritmatika kemudian data dikeluarkan dalam bentuk perintah (Right, Left, Nose Up, Nose Down) ke Dji Tello melalui wireless.

\section{B. Pengujian Sudut Sensor}

Pengujian dilakukan dengan menjabarkan nilai sudut MPU6050 terhadap sudut gerak yang diberikan. Nilai X adalah gerak roll baik ke kanan dan ke kiri dengan nilai positif(+) ke kanan dan nilai (-) ke kiri . Nilai Y adalah gerak pitch baik ke atas maupun ke bawah dengan nilai (+) ke bawah dan nilai (-) ke atas dengan waktu yang diberikan selama 10 detik dengan jeda 0.5 second. Perubahan nilai sudut MPU6050 terhadap waktu dengan variabel sumbu roll dan pitch baik pada nilai data kalman filter di Arduino Uno. Gambar 6 menjelaskan pengujian inilai sudut yang diukur berdasarkan variabel yang telah ditetapkan untuk mengendalikan gerak pada drone Dji Tello berupa gerak roll dan Pitch.

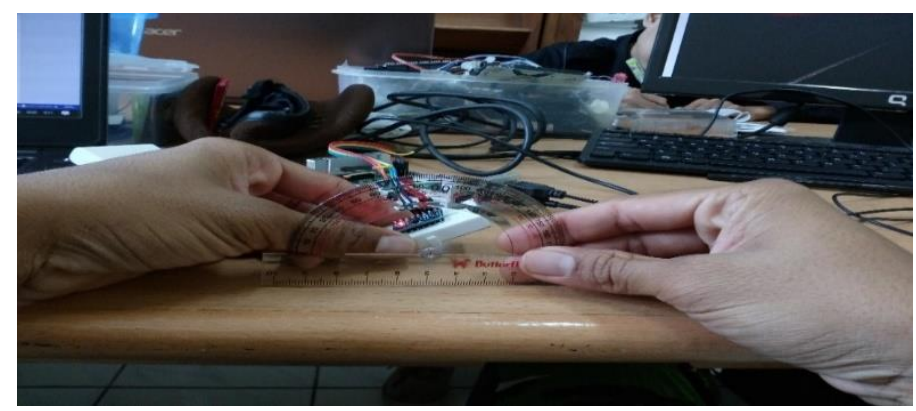

Gambar 6. Pengujian sudut dengan jangka ukur

1. Pitch. Dari penelitian gerak maju dilakukan dengan cara memiringkan tangan ke arah atas pada nilai acuan untuk gesture maju ini adalah $30^{\circ}$ sampai dengan $60^{\circ}$ pada sudut pitch. Untuk Gesture mundur dengan cara memiringkan tangan ke bawah pada nilai acuan untuk gesture maju ini adalah $-30^{\circ}$ sampai dengan $-60^{\circ}$ pada sudut pitch. Gesture take off dan naikk digunakan untuk mengontrol drone melakukan gerakan naik. Gesture ini dilakukan dengan cara memiringkan tangan ke arah atas untuk memudahkan pengguna dan juga kemiripan gesture tersebut dengan pergerakkan take off dan naik drone. Gesture ini didefinisikan dengan cara menyimpan nilai acuan yang digunakan sebagai pembanding dengan nilai transformasi sudut yang dideteksi sensor MPU6050 berdasarkan sudut pitch. Nilai acuan untuk gesture take off dan naik ini adalah $60^{\circ}$ sampai dengan $90^{\circ}$ pada sudut pitch. Gesture landing dan turun digunakan untuk mengontrol drone melakukan gerakan landing dan turun. Gesture ini dilakukan dengan cara memiringkan tangan ke bawah sehingga terjadi pergerakkan landing dan turun pada drone. Gesture ini didefinisikan dengan cara menyimpan nilai acuan yang digunakan sebagai pembanding dengan nilai transformasi sudut yang dideteksi sensor MPU6050 berdasarkan sudut pitch. Nilai acuan untuk gesture landing ini adalah $-60^{\circ}$ sampai dengan $-90^{\circ}$ pada sudut pitch. Gambar 7.a menjelaskan hasil dari MPU dengan jumlah data 362 pengambilan data setelah difilter mempunyai variasi yang sangat minimal 0.0016613 tetapi data masih menyebar. Pada Gambar 7.b menjelaskan dari MPU dengan jumlah data 362 pengambilan data setelah difilter mempunyai variasi yang sangat minimal 0.00564 dengan data mengumpul di range 89.30 sampai 89.25 . 

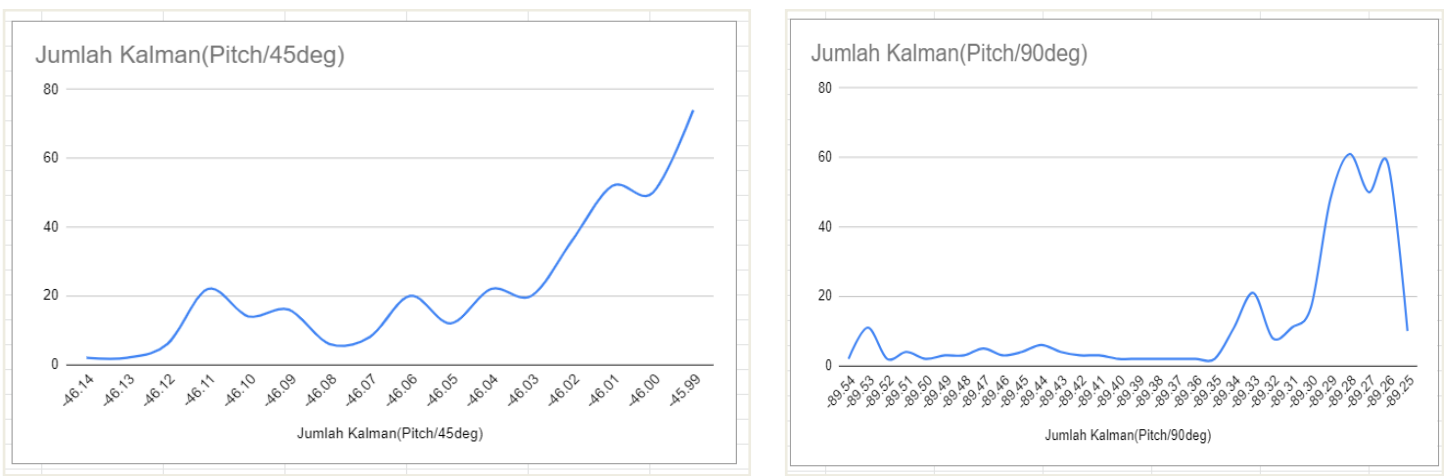

Gambar 7. Data Pitch 49 derajat dan Data Pitch 90 derajat

2. Roll. Dari penelitian Gesture manuver ke kanan dengan cara memiringkan tangan ke arah samping kanan pada nilai acuan untuk gesture manuver ke kanan ini adalah $>30^{\circ}$ sampai dengan $90^{\circ}$. Untuk gesture manuver ke kiri dengan cara memiringkan tangan ke arah samping kiri pada nilai acuan untuk gesture geser ke kiri ini adalah $<-30^{\circ}$ sampai dengan $-90^{\circ}$ pada sudut roll. Gesture hover digunakan untuk mengontrol drone melakukan hover. Hover yaitu suatu keadaan pada saat mempertahankan posisi nya. Ketika hover, drone akan mempertahan posisi ketinggian dan juga tidak melakukan pergerakan roll dan pitch. Gesture ini dilakukan dengan cara meluruskan tangan sejajar dengan lengan bawah. Gesture ini didefinisikan dengan cara menyimpan nilai acuan yang digunakan sebagai pembanding dengan nilai transformasi sudut yang dideteksi sensor MPU6050. Nilai acuan tersebut berdasarkan sudut roll, pitch. Nilai acuan untuk gesture hover adalah $-30^{\circ}$ sampai $30^{\circ}$ pada sudut roll dan $-30^{\circ}$ sampai $30^{\circ}$ pada sudut pitch. Pada Gambar 8.a menjelaskan dari MPU dengan jumlah data 362 pengambilan data setelah difilter mempunyai variasi yang sangat minimal 0.0141285 dengan data menyebar. Pada Gambar 8.b menjelaskan dari MPU dengan jumlah data 362 pengambilan data setelah difilter mempunyai variasi yang sangat minimal 0.0141285 dengan data relatif mengumpul pada range 90.42 sampai 90.44 .
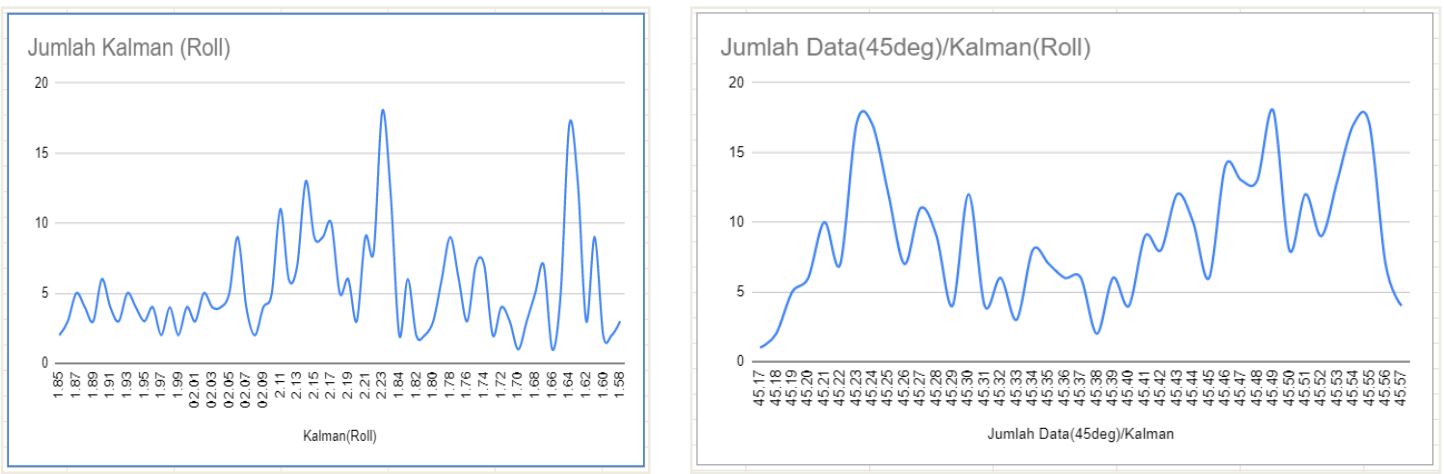

Gambar 8. Roll 0 derajat dan Roll 45 derajat

\section{Pengujian Hand Gesture}

Pengujian mendeteksi hand gesture dilakukan sebanyak 5 kali pada setiap gerak yang dilakukan sehingga total pengujian sebanyak 20 kali. Setelah dilakukan pengujian didapat hasil berupa jumlah pengujian yang benar pada saat sistem mendeteksi hand gesture pengguna. Jumlah pengujian yang benar tersebut kemudian dibandingkan dengan jumlah pengujian yang dilakukan untuk mendapatkan keberhasilan mendeteksi hand gesture setelah menerapkan metode kalman 
filter. Pada pengujian ini hand gesture yang diuji mempunyai waktu delay $25.661667 \mathrm{~ms}$, hal ini sebagai akibat waktu dibutuhkan untuk proses kalman filter, komunikasi data dari arduino Ke PC dan proses pendekodean PC menjadi perintah ke Dji Tello dengan komunikasi wireless. Pada Tabel 2 dapat dilihat bahwa seluruh pengujian yang dilakukan mendapatkan keberhasilan semuanya sesuai dengan banyak pengujian sehing pengujian ketepatan gerakan diperoleh akurasi sebesar $100 \%$ terhadap hubungan ketepatan gerakan antara hand gesture dan pergerakan drone. Hasil tersebut berdasarkan dari rumus yang telah kita tetapkan pada bab sebelumnya . Pengujian dilakukan 5 kali disetiap gerak sehingga total pergerakan berjumlah 20 kali dan semua dari pergerakan tersebut mendapat akurasi $100 \%$.

TABEL 2

PENGUJIAN MENDETEKSI HAND GESTURE

\begin{tabular}{|l|c|c|l|}
\hline \hline \multicolumn{1}{|c|}{ Nama Gesture } & Banyak pengujian & Pengujian benar & Status keberhasilan \\
\hline & 5 & 5 & \\
Pitch Up & 5 & 5 & Berhasil \\
\hline Pitch Down & 5 & 5 & Berhasil \\
\hline Gesture Roll Kanan & 5 & 5 & Berhasil \\
\hline Gesture Roll Kiri & & & \\
\hline
\end{tabular}

\section{KESIMPULAN}

Berdasarkan tahap perancangan dan penelitian yang dilakukan, dapat ditarik beberapa kesimpulan sebagai berikut :

a. Kalman Filter menujukn meningkatkan akurasi output sensor IMU dengan nilai error yang kecil

b. Pada penelitian ini hasil data masih meyebar sehingga tidak konvergen dan terjadi drifting pada initial value

c. Perlu pengembangan algoritma Kalman Filter dengan variebel yang mempertingkan non linearity dari system

d. Sistem Komunikasi data pada penelitian masih terjadi penundan waktu delay 25.661667 ms sehingga diperlukan penelitian yang memperbaiki waktu tunda pengendalian. Bagian kelima ini adalah kesimpulan dari penelitian yang telah dilakukan dan dibahas dalam naskah ini. Uraiannya meliputi kesimpulan pada alinea pertama dan saran untuk penelitian mendatang.

Dari hasil penelitian, terdapat beberapa saran yang dapat dijadikan masukan bagi pengembangan selanjutnya, yaitu :

a. Penggunaan sistem komunikasi wireless tidak menggunakan PC tetapi langsung ke Arduino tipe Arm yang menyatu dengan sistem wireless.

b. Data masih meyebar kemungkinan sistem berlaku kendali system non linear sehingga perlu ada pengembangan algoritma Kalman Filter agar algoritma menjadi konvergen.

\section{UCAPAN TERIMA KASIH}

Ucapan terimakasih yang telah mendorong dan membantu penelitian ini sehingga kami dapat melesaikan penelitian ini kepada :
a. Gubernur dan Wakil Gubernur AAU .
b. Kepala Departemen Elektronika AAU
c. Koordostur AAU 


\section{REFERENSI}

[1] Teppo Luukkonen, 2011, "Modelling and control of quadcopter", School of Science, Independent research project in applied mathematics.

[2] Hadi, S. W. S. G. E. \& Maulana, R., 2017. Sistem Kendali Navigasi Ar.Drone Quadcopter Dengan Prinsip Natural User Interface Menggunakan Microsoft Kinect. Jurnal Pengembangan Teknologi Informasi dan Ilmu Komputer (JPTIIK), Volume 2, pp. 380-386 dilihat 9 September 2019 <http://j-ptiik.ub.ac.id>..

[3] Andi Susanto, . Pramono, S. Widada, W, 2009b, "Simulasi Filter Kalman Untuk Estimasi Sudut

Dengan Menggunakan Sensor Gyroscope" TEKNIK - Vol. 30 No. 2 Th 2009, ISSN 0852-1697. $98=104$.

[4] Wahyudi. Susanto, A. Pramono, S. Widada, W, 2009b, "Simulasi Filter Kalman Untuk Estimasi Sudut Dengan Menggunakan Sensor Gyroscope”. TEKNIK - Vol. 30 No. 2 Tahun 2009, ISSN 0852-1697. p 98 - p 104A. .

[5] Welch G, Bishop G. 2004. "An Introduction to the Kalman Filter", University of North Carolina at Chapter Hill

[6] S G Vijayakumari,Hand Gesture Controlled Aerial Surveillance Drone, Volume 119 No. 15 , 897-901, International Journal of Pure and Applied Mathematics, 2018.

[7] Ayanava Sarkar dkk, Gesture Control of Drone Using a Motion Controller, www.researchgate.net/publication/301800528, th 2016.

[8] Kathiravan Natarajan dkk, Hand Gesture Controlled drone : Open Source Librarry, www.researchgate.net/publication/324485264

[9] Amelio Eric Fransisco dkk, Sistem Kendali Navigasi Robot Beroda dengan Gestur Tangan Menggunakan Metode Kalman Filter, Vol. 3, No. 8, Agustus 2019, hlm. 7955-7962, Jurnal Pengembangan Teknologi Informasi dan Ilmu Komputer,www. j-ptiik.ub.ac.id 